\title{
PR-25. RESTORATION OF CATALYTIC ACTIVITY OF THE DRAWING OF THE PRINTED CIRCUIT BOARD AT PHOTOSELECTIVE ACTIVATION OF FIBREGLASSES
}

\author{
L. A. Brusnitsina, E. I. Stepanovskih, T. A. Alekseeva \\ Ural Federal University of the first President of Russia B. N. Yeltsin, \\ Mira St., 19, Yekaterinburg, 620002, Russia \\ E-mail: brusnitsyna.1@yandex.ru
}

In the production technology of printed circuit boards by an additive method photoselective activation of dielectric materials finds broad application. The photoadditive technology is a multistage process. Photosensitive compositions for activation of dielectrics are the difficult multicomponent systems which are turning on the photopro-motor (copper acetate), an optical sensitizer (sodium salts of anthraquinonesulfonic acids), secondary reducer (sorbite, ethyl alcohol), the component (citric acid) interfering process of hydrolysis of the photopro-motor and maintaining value $\mathrm{pH}$ solution at the set level [1].

The major requirement to activation of a surface is ensuring high catalytic activity of the metallized substrate which is defined by the nature of the catalyst of sedimentation of copper in solutions of a chemical copper plating. The high catalytic activity of the metallized surface provides sedimentation of compact, strong and uniform films of metal.

Catalystically active centers need to be created under the influence of ultra-violet radiation for obtaining the set drawing of the scheme on a surface and in openings of the printed circuit board at further chemical metallization. Restoration of copper (II) to copper (I) and to metal happens in the course of exhibiting of a photosensitive layer on the basis of compounds of copper (II). The formed drawing of the scheme consists generally of particles of a gemioksid of copper, metal copper and oxide of copper. Loss of activity by some sites of a surface results from oxidation, pollution, dissolution or washing off of particles of the catalyst [2].

The complete recovery of copper (II) and copper (I) is received in the solutions containing except alkali and formaldehyde of copper complexing agent: trilon B, sodium-potassium tartrate, ethylenediamine. Reliable restoration of catalytic activity of the drawing of the printed circuit board happens at a temperature of $20-25{ }^{\circ} \mathrm{C}$ during processing of 3-5 min. At interaction of solution of this structure and a gemioksid of copper metal copper and a soluble complex of copper (II) from which copper (II) is restored in water alkaline solutions by formaldehyde to metal is formed [3].

$$
\mathrm{Cu}_{2} \mathrm{O}+\mathrm{H}_{2} \mathrm{O}+\mathrm{C}_{4} \mathrm{H}_{4} \mathrm{O}_{6}^{2-}=\mathrm{Cu}^{0}+\mathrm{Cu}(\mathrm{OH})_{2} \mathrm{C}_{4} \mathrm{H}_{4} \mathrm{O}_{6} \text {. }
$$

Potassium-sodium tartrate is used as a ligand in technological process with tartratny solution of a thicklayer chemical copper plating. Then after restoration of catalytic activity of the drawing of the scheme the printed circuit board can be brought in solution of a thick-layer chemical medneniye without intermediate washing.

\section{References}

1. Полная исследовательская публикация «Моделирование процесса фотовосстановления меди (II) в твердой фазе» / Л. А. Брусницына [и др.] // Бутлеровские сообщения. 2012. Vol. 29. P. 75-79.

2. Батлер Дж. Н. Ионные равновесия. Л. : Химия. Ленингр. отд-ние, 1973. 446 с.

3. Шалкаускас М. И., Вашкялис А. И. Химическая металлизация пластмасс. 3-е изд., перераб. Л. : Химия. Ленингр. отд-ние, 1985. 144 с. 